Case Report

\section{Giant prolactinoma case with side effects due to cabergoline}

\author{
Semiha Çalkaya*, Fahri Bayram, Ali Kurtsoy and Hüseyin Dursun \\ Department of Endocrinology, Erciyes University, Medical School, Kayseri, Turkey
}

\section{Abstract}

Dopamine agonists should usually be the first treatment for patients with prolactinomas of all sizes, because these drugs decrease serum prolactin concentrations and decrease the size of most lactotroph adenomas. Cabergoline is preferred first. When cabergoline develops side effects bromokriptin is switched. Cabergoline is more efficient than bromocriptine. Its side effect profile more favorable than bromocriptine. Cabergoline is an ergot dopamine agonist that is administered once or twice a week. Cabergoline can have rarely serious psychiatric adverse effects, including psychosis, impulse control disorders, dyskinesia, pulmonery fibrosis and valvular heart disease.

Prolactinomas are the most common pituitary tumors, $93 \%-95 \%$ of the cases are microadenomas. Macroprolactinomas larger than $40 \mathrm{~mm}$, known as giant prolactinomas, are exceptionally rare, accounting for $0.5 \%-4 \%$ of all prolactin-hypersecreting adenomas.

In our case, after the $7 \times 6 \mathrm{~cm}$ giant macroprolactinoma operated we report the manic episode occuring during the second week of cabergoline treatment. In the treatment of patients with prolactinoma, cabergoline is a first choice drug because it has a better tolerance profile and is more effective, however, bromocriptine can be switched to when drug resistance or side effects develop to cabergoline.

\section{More Information}

*Address for Correspondence: Semiha Çalkaya, Department of Endocrinology, Kahramanmaraş Sütçü İmam University, Turkey,

Tel: 05448513534;

Email: semihacalkaya@hotmail.com

Submitted: 11 February 2020

Approved: 13 March 2020

Published: 16 March 2020

How to cite this article: Çalkaya S, Bayram F, Kurtsoy A, Dursun H. Giant prolactinoma case with side effects due to cabergoline. Arch Case Rep. 2020; 4: 012-014.

DOI: 10.29328/journal.acr.1001031

ORCiD: orcid.org/0000-0002-0178-1879

Copyright: (c) 2020 Çalkaya S, et al. This is an open access article distributed under the Creative Commons Attribution License, which permits unrestricted use, distribution, and reproduction in any medium, provided the original work is properly cited.

Keywords: Macroprolactinoma; Cabergoline side effects; Bromocriptine

Check for updates

OPEN ACCESS

\section{Introduction}

Prolactinomas are the mostcommon pituitary tumors, often seen as microadenomas, and treatment is usually medical. Treatment of patients with lactotroph macroadenomas, no matter how large or how severe the neurologic symptoms, should also be initiated with a dopamine agonist, starting with cabergoline [1]. Patients whose macroadenomas are largely cystic should also be treated initially with a dopamine agonist since this treatment shrinks most of these [2]. Cabergoline, a dopamine agonist is generally used in the treatment of hyperprolactinemia, Parkinson's disease, restless leg syndrome, and antipsychotic-induced prolactin elevation. It is generally well tolerated as compared to other dopamine agonist due to its more selective D2 receptor agonistic effect [3]. However, it can cause certain psychiatric side effects including psychosis, depression, impulse control disorders, and nightmares [4].

Prolactin (PRL)-secreting pituitary adenomas (PRLomas) are the most common pituitary secreting tumors, accounting for $32 \%$ - $45 \%$ of all pituitary tumors [5-7]. Prolactinomas are most often microadenomas $(<10 \mathrm{~mm}$ in diameter $)$ and are diagnosed more frequently in women, who usually present with the hormonal sequelae of hyperprolactinemia including galactorrheaand oligomenorrhea. In men, macroprolactinomas ( $>10 \mathrm{~mm}$ in diameter) are more commonly detected, and it has been hypothesized that the greater subtlety of male hormonal symptoms of hyperprolactinemia, gynecomastia, decreased libido, and impotence may account for the lower observed frequency and the larger size of clinically evident prolactinomas in men [8]. Giant prolactinomas are pituitary adenomas larger than $4 \mathrm{~cm}$ in size presenting very high serum prolactin levels (typically above $1000 \mathrm{ng} / \mathrm{mL}$ ) and no concomitant growth hormone (GH) or adrenocorticotropic hormone (ACTH) hypersecretion. They represent less than 5 $\%$ of all prolactinomas $[9,10]$.

Here we present a case of a 33-year-old male who had $7 \times 6 \mathrm{~cm}$ macroadenom. Occured manic episode, personality changes and hallucinations, following the started cabergoline treatment after surgery, thereon bromocriptin therapy was started.

\section{Case report}

A 33-year-old male patient attended to ophthalmologist with a bilateral visuel loss for four-five years.

He reported no history of galactorrhea, gynecomastia, but have headaches have and decreased libido. Then he 
referred to endocrinologist. In laboratory examinations, hyperprolactinemia ( $>200 \mathrm{ng} / \mathrm{mL}$ ) and hypogonadotropic hypogonadism, were detected (Figure 1 and Table 1).

He was started on cabergoline $0.25 \mathrm{mg}$ twice weekly, prednisone tablet 7,5 mg/daily and testosterone $250 \mathrm{mg}$ IM injection every 3 weeks. Patient was hospitalized for treatment. After a week of cabergoline treatment patient had an epileptic attack due to apoplexi. The patient was urgently opereted. Postoperative patient was followed and discharged. Pathologic examination showed that; the tumor cells were positive for prolactin and luteinizan hormone (LH), follicle stimulating hormone (FSH), growth hormone (GH), thyroid stimulating hormone (TSH) were negative. Patient was brought to the emergency department by his relatives hallucinations, personality changes and manic episodes. The patient was evaluated by the psychiatry in the emergency department.These complaints seen in the patient were related to the side effect of the cabergolin. Therefore, bromocriptin treatment was started $1,25 \mathrm{mg} /$ day and increased to $5 \mathrm{mg}$ /day on this patient. There was no side effect with this treatment.

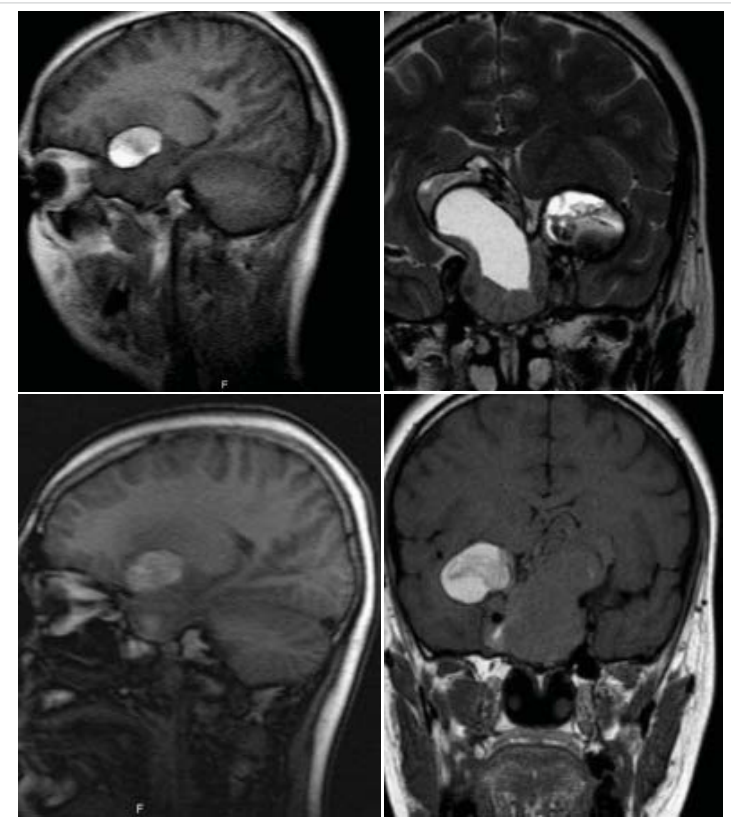

Figure 1: MR scan showed that pituitary macroprolactinoma.

Table 1: Hormonal profile at presentation.

\begin{tabular}{|c|c|c|}
\hline Biomarker & Value & Normal References \\
\hline Prolactin $\mathrm{ng} / \mathrm{ml}$ & $>470$ & $4.04-15,2$ \\
\hline $\mathrm{GH} \mathrm{ng} / \mathrm{ml}$ & 0.566 & $0-1$ \\
\hline $\mathrm{IGF}-1 \mathrm{ng} / \mathrm{ml}$ & 44.8 & $115-307$ \\
\hline $\mathrm{ACTH} \mathrm{pg} / \mathrm{ml}$ & 12.6 & $0-46$ \\
\hline $\mathrm{FSH} \mathrm{mlU} / \mathrm{ml}$ & 0.549 & $1.5-12.4$ \\
\hline $\mathrm{LH} \mathrm{mlU} / \mathrm{ml}$ & 0.56 & $1.7-8.6$ \\
\hline Serum cortisol $\mu \mathrm{g} / \mathrm{dl}$ & 4.9 & \\
\hline Free T4 $\mathrm{ng} / \mathrm{dl}$ & 1.1 & $0.93-1.97$ \\
\hline TSH $\mu \mathrm{lU} / \mathrm{ml}$ & 4.09 & $0.27-4.2$ \\
\hline Total serum testosterone $\mathrm{ng} / \mathrm{dl}$ & $<2.50$ & $280-800$ \\
\hline
\end{tabular}

Abbreviations: ACTH: Adrenocorticotropic Hormone; FSH: Follicle Stimulating Hormone; GH: Growth Hormone; IGF: Insulin-like Growth Factor; LH: Luteinizing Hormone; TSH: Thyrotropin

\section{Discussion}

Mesocortical and mesolimbic D2 and D3 receptors are thought to be involved in mood and behavior, and dopamine agonists can trigger psychosis or mania [11-13]. Impulse control disorders (ICDs), including problem gambling, hypersexuality, compulsive eating and compulsive shopping, may be mediated by D3 receptors in the mesolimbic system $[12,13]$. D2 receptor agonistic effect of cabergoline is responsible for manic episode. İnitially high dose ( $0.5 \mathrm{mg}$ per day) of cabergoline is associated with risk of psychosis [14]. However, no literature is available regarding relation between very low dose of cabergoline with giant macroprolactinoma.

In general, medically treated prolactinomas have a high remission rate of $90 \%$ [6]. When they are large and extend outside the sellar borders, the rate of prolactin normalization decreases to $70 \%-80 \%$ for macroprolactinomas [6] and $60 \%-68 \%$ for giant prolactinomas $[9,10]$.

Transsphenoidal or transcranial resection may be offered to the subset of patients with giant prolactinoma for whom even high-dose medical therapy fails to achieve tumor size and hormonal control [15], and patients with apoplexy or complications of pharmacological treatment (CSF leak). The reported rate of surgery following first-line dopamine agonist treatment is nearly 15\% [9]. Severe chiasmal pressure might also lead to a decision to operate, although even severe optic damage and significant visual field defects can improve with medical treatment alone $[9,10]$. However, surgery is rarely curative. Most patients will not achieve hormonal remission postoperatively $[6,9]$, will remain with a significant adenoma residue, and will require continuous medical treatment. Surgical resection may also be hampered by intratumoral fibrosis, which may develop following long-term dopamine agonist management [16,17]. Moreover, surgery in patients with gigantic tumors can be associated with complications such as diabetes insipidus, mental deterioration, CSF leak, meningitis, worsening vision, and even perioperative mortality [18].

Although cabergoline is highly effective in hyperprolactinemia treatment, it may induce hypomanic/manic episodes, pituitary apoplexi, personality changes and hallucinations such as in this case. Risk-benefit ratio should be analyzed with prospective controlled studies in future and cabergoline must be used carefully. Alternatively other drugs (e.g., bromocriptin, quinagolide) should be kept in mind. But there are more than other side effect profile (nausea, vomiting, dizziness) and should be taken every day. Cabergoline is an effective drug but it should be kept in mind that cabergoline may develop side effects even at very low doses.

Giant prolactinomas are generally benign but they may be aggressive and invasive, disrupting nearby structures and higher serum prolactin levels. They show a fairly good response to medical treatment with dopamine agonists, combined with surgery in some patients and radiotherapy if required. 


\section{References}

1. Melmed S, Casanueva FF, Hoffman AR, Kleinberg DL, Montori VM, et al. Diagnosis and treatment of hyperprolactinemia: an Endocrine Society clinical practice guideline. J Clin Endocrinol Metab. 2011; 96: 273. PubMed: https://www.ncbi.nlm.nih.gov/pubmed/21296991

2. Faje A, Chunharojith P, Nency J, Biller BM, Swearingen B, et al. Dopamine Agonists Can Reduce Cystic Prolactinomas. J Clin Endocrinol Metab. 2016; 101: 3709.

PubMed: https://www.ncbi.nlm.nih.gov/pubmed/27459530

3. Webster J, Piscitelli G, Polli A, Ferrari $\mathrm{Cl}$, Ismail I, Scanlon MF. A comparison of cabergoline and bromocriptine in the treatment of hyperprolactinemic amenorrhea. Cabergoline Comparative Study Group. N Engl J Med. 1994; 331: 904-909.

PubMed: https://www.ncbi.nlm.nih.gov/pubmed/7915824

4. Harris YT, Harris AZ, Deasis JM, Ferrando SJ, Reddy N, Young RC. Cabergoline associated with first episode mania. Psychosomatics. 2012; 53: 595-600.

PubMed: https://www.ncbi.nlm.nih.gov/pubmed/22658326

5. Ciccarelli A, Daly AF, Beckers A. The epidemiology of prolactinomas. Pituitary. 2005; 8: 3-6.

PubMed: https://www.ncbi.nlm.nih.gov/pubmed/16411062

6. Gillam MP, Molitch ME, Lombardi G, Colao A. Advances in the treatment of prolactinomas. Endocr Rev. 2006; 27: 485-534.

PubMed: https://www.ncbi.nlm.nih.gov/pubmed/16705142

7. Tjörnstrand A, Gunnarsson K, Evert M, Holmberg E, Ragnarsson O, et al. The incidence rate of pituitary adenomas in western Sweden for the period 2001-2011. Eur J Endocrinol. 2014; 171: 519-526. PubMed: https://www.ncbi.nlm.nih.gov/pubmed/25084775

8. Pinzone J J, Katznelson L, Danila D C, Pauler D K, Miller C S, Klibanski A. Primary medical therapy of micro- and macroprolactinomas in men. $J$ Clin Endocrinol Metab. 2000; 85: 3053-3057.

PubMed: https://www.ncbi.nlm.nih.gov/pubmed/10999785

9. Maiter D, Delgrange E. Therapy of endocrine disease: the challenges in managing giant prolactinomas. Eur J Endocrinol. 2014; 170: R213R227.

PubMed: https://www.ncbi.nlm.nih.gov/pubmed/24536090
10. Moraes AB, Silva $C M$, Vieira Neto L, Gadelha MR. Giant prolactinomas: the therapeutic approach. Clin Endocrinol. 2013; 79: 447-456. PubMed: https://www.ncbi.nlm.nih.gov/pubmed/23662975

11. Ali S, Klahr K, Freudenreich 0. 2015. Management of psychosis associated with a prolactinoma: case and review of the literature. Psychosomatics 51 2010. 370-376.

PubMed: https://www.ncbi.nlm.nih.gov/pubmed/20833935

12. Kvernmo T, Houben J, Sylte I. Receptor-binding and pharmacokinetic properties of dopaminergic agonists. Current Topics in Medicinal Chemistry 8 1049-1067.

PubMed: https://www.ncbi.nlm.nih.gov/pubmed/18691132

13. Noronha S, Stokes V, Karavitaki N \& Grossman A. Treating prolactinomas with dopamine agonists: always worth the gamble?. Endocrine In press.

PubMed: https://www.ncbi.nlm.nih.gov/pubmed/26336835

14. Chang SC, Chen CH, Lu ML. Cabergoline-induced psychotic exacerbation in schizophrenic patients. Gen Hosp Psychiatry. 2008; 30: 378-380.

PubMed: https://www.ncbi.nlm.nih.gov/pubmed/26336835

15. Andujar-Plata $P$, Villar-Taibo $R$, Ballesteros-Pomar MD, Vidal-Casariego A, Pérez-Corral B, et al. Long-term outcome of multimodal therapy for giant prolactinomas. Endocrine. 2017: 55: 231-238.

PubMed: https://www.ncbi.nlm.nih.gov/pubmed/27704480

16. Bevan JS, Adams CB, Burke CW, Morton KE, Molyneux AJ, et al. Factors in the outcome of transsphenoidal surgery for prolactinoma and nonfunctioning pituitary tumour, including pre-operative bromocriptine therapy. Clin Endocrinol (Oxf). 1987; 26: 541-556.

PubMed: https://www.ncbi.nlm.nih.gov/pubmed/3665118

17. Mohan N, Chia YY, Goh GH, Ting E, Teo K, et al. Cabergoline-induced fibrosis of prolactinomas: a neurosurgical perspective. BMJ Case Rep. 2017; 2017: bcr-2017-220971.

PubMed: https://www.ncbi.nlm.nih.gov/pubmed/29102970

18. Garibi J, Pomposo I, Villar G, Gaztambide S. Giant pituitary adenomas: clinical characteristics and surgical results. Br J Neurosurg. 2002; 16: 133-139.

PubMed: https://www.ncbi.nlm.nih.gov/pubmed/12046731 